\title{
Natural occurrence of Beauveria spp. in outbreak areas of cockchafers (Melolontha spp.) in forest soils from Poland
}

\author{
Marzena Niemczyk (D) Alicja Sierpińska • Anna Tereba $\cdot$ Karol Sokołowski • \\ Pawel Przybylski
}

Received: 9 May 2018/Accepted: 7 February 2019/Published online: 14 February 2019

(C) The Author(s) 2019

\begin{abstract}
We investigated the occurrence and pathogenicity of Beauveria spp. (Hypocreales: Cordycipitaceae) in forest soils in Poland, in outbreak areas of cockchafers (Coleoptera: Scarabaeidae): Melolontha melolontha L. and M. hippocastani F. We also examined the occurrence of Beauveria in relation to soil $\mathrm{pH}$. Beauveria spp. isolates were characterised at species and genotype levels using ITS and microsatellite markers. Beauveria spp., which were detected at over $80 \%$ of sites, were sensitive to $\mathrm{pH}$, preferring
\end{abstract}

Handling Editor: Helen Roy

M. Niemczyk $(\bowtie) \cdot$ P. Przybylski

Department of Silviculture and Forest Tree Genetics, Forest Research Institute, Braci Leśnej 3, Sękocin Stary, 05-090 Raszyn, Poland

e-mail: M.Niemczyk@ibles.waw.pl

A. Sierpińska

Department of Forest Protection, Forest Research Institute, Braci Leśnej 3, Sękocin Stary, 05-090 Raszyn, Poland

e-mail: A.Sirpinska@ibles.waw.pl

\section{A. Tereba}

Department of Forest Ecology, Forest Research Institute, Braci Leśnej 3, Sękocin Stary, 05-090 Raszyn, Poland e-mail: A.Tereba@ibles.waw.pl

\section{K. Sokołowski}

Loboratory of Natural Environment Chemistry, Forest

Research Institute, Braci Leśnej 3, Sękocin Stary,

05-090 Raszyn, Poland

e-mail: K.Sokolowski@ibles.waw.pl neutral or alkaline soils. This suggests that the acidity of forest soils in Poland can affect their efficacy as biological control agents (BCAs). B. brongniartii (Sacc.) Petch as a pathogen of cockchafers occurred at $41 \%$ of sites, but often at densities below the threshold values for infection, and it infected only $1.3 \%$ of cockchafer grubs. Our results suggest that B. brongniartii genotype isolated from cockchafers in forest soils can potentially expand the pool of BCAs in this environment.

Keywords Melolontha Beauveria brongniartii . Soil PH · Entomopathogenic fungi · Outbreak area . Forest soil

\section{Introduction}

Cockchafers (Melolontha spp.) are the most damaging root pests in forest ecosystems in many European countries, including Poland (Blaisinger 1988; Dolci et al. 2006; Fodor et al. 2005; Keller 1988; Malinowski et al. 1996; Niemczyk 2015; Niemczyk et al. 2017; Strasser and Schinner 1996; Švestka 2006, 2010; Wagenhoff et al. 2014). Due to the lack of insecticides registered against Melolontha spp. (Directive 2009/ 128/EC of the European Parliament and of the Council), biological methods are needed.

During the last several decades, biological control agents (BCAs) have been identified as feasible 
alternatives to chemical pest treatments (Canfora et al. 2016; Mazid et al. 2011). Although numerous studies have identified and evaluated beneficial bacteria and fungi strains that are pathogenic to insects, the application of BCAs in forestry is still limited by several factors. First, the inoculants are mainly isolated from agricultural soils, which can affect their viability and persistence in different habitats, such as natural forest soil environments. Many studies have shown that the persistence and efficacy of entomopathogenic hyphomycetous fungi in soil depends on complex interactions of intrinsic, edaphic, biotic, and climatic factors (Goble et al. 2012; Kessler et al. 2003; Scheepmaker and Butt 2010). The use of inundative, inoculative, conservative, or classical approaches for fungal BCAs requires an understanding of the biology and ecology of the fungi and different biotic and abiotic factors present (Jackson et al. 2010; Lacey et al. 2015; Meyling and Eilenberg 2007). Soil $\mathrm{pH}$ is an abiotic factor that can affect the survival, ecological distribution, and virulence of entomopathogenic fungi (Galani 1988; Inglis et al. 2001; Padmavathi et al. 2003; Sanzhimitupova 1980; Sharma et al. 1992). Due to the influence of soil $\mathrm{pH}$, the actual effects of BCAs may differ from the predicted results. Assessing natural infection rates and the occurrence of entomopathogenic fungi in forest environments in areas where there are mass outbreaks of pests provides a behavioural baseline for these organisms and is thus a key task for improving BCA strain selection and efficacy.

One of the most important entomopathogenic fungal genera distributed worldwide is Beauveria (Bals.) Vuill. (Ascomycota: Hypocreales) (Imoulan et al. 2017; Li et al. 2001). In Europe, the most prevalent natural pathogen of Melolontha spp. is Beauveria brongniartii (Saccardo) Petch, which infects all developmental stages of these pests (Trzebitzky 1996). Because of the ability of B. brongniartii to specifically infect and kill insects, several strains have been tested and used commercially as BCAs against cockchafer grubs in various European countries (Enkerli et al. 2001, 2004; Keller et al. 1997; Mayerhofer et al. 2015; Sierpińska 2008; Strasser and Enkerli 2001; Strasser et al. 2000). These BCAs have been tested in agricultural and forest environments, but in the latter no satisfactory results have been achieved (Sierpińska et al. 2015). The identification of edaphic factors in natural forest habitats (soil types, $\mathrm{pH}$ ranges, etc.) that influence the occurrence and distribution of Beauveria spp. in the soil will help to improve the efficacy of biological control in forests. Simultaneously, the identification of indigenous entomopathogenic fungi from the forest soil environment can provide insight into naturally occurring fungal biodiversity and can expand the pool of potential BCAs for pest control purposes. The aims of the present study were therefore to: (1) investigate the natural occurrence and density of Beauveria spp. in forest soils in areas of cockchafer outbreaks in Poland, (2) characterise Beauveria species richness and variability, (3) investigate the effects of soil $\mathrm{pH}$ ranges and edaphic factors on the occurrence of Beauveria spp., and (4) determine the rate of natural infection of cockchafer grubs caused by $B$. brongniartii.

\section{Materials and methods}

Study sites

Research plots were selected in areas in Poland that experience outbreaks of cockchafers, and where these insect pests cause the most serious economic losses in forestry. The sites were in three forest districts in central and southeastern Poland: Ostrowiec Świętokrzyski $\quad\left(50^{\circ} 56^{\prime} 00^{\prime \prime} \mathrm{N} \quad 21^{\circ} 24^{\prime} 00^{\prime \prime} \mathrm{E}\right)$, Lubaczów $\left(50^{\circ} 09^{\prime} 33^{\prime \prime} \mathrm{N} 23^{\circ} 07^{\prime} 19^{\prime \prime} \mathrm{E}\right)$, and Narol $\left(50^{\circ} 21^{\prime} 01^{\prime \prime} \mathrm{N}\right.$ $\left.23^{\circ} 19^{\prime} 38^{\prime \prime} \mathrm{E}\right)$. The mean annual temperature ranged from $7.2{ }^{\circ} \mathrm{C}$ in Lubaczów to $8.3{ }^{\circ} \mathrm{C}$ in Ostrowiec Św. The annual rainfall exceeded $700 \mathrm{~mm}$ at all research sites, and the growing season lasted for approximately 200 days. Detailed information on research sites is given in Table 1.

\section{Study design}

Research was carried out at 12 stands (sites) from 2013 to 2014. Sites were chosen in the two most representative (i.e., most common) forest site types for the selected forest districts: fresh broad-leaved forest (six sites) and fresh mixed broad-leaved forest (six sites). Forest site types were classified according to geographical climatic conditions, spatial structure, species composition, site index, physiographical climatic factors, and undergrowth vegetation (Kliczkowska et al. 2003). Preliminary identification of cockchafer grubs was carried out in 2013. At each site, 25 
Table 1 Basic characteristic of forest research sites in Poland. Each site was characterised (in accordance with Instrukcja ochrony lasu (2012) as a forested area that was homogeneous in terms of habitat conditions and forest stand elements (dominant tree species, age, spatial structure, site index, forest site type, etc.)

\begin{tabular}{|c|c|c|c|c|c|c|c|c|}
\hline $\begin{array}{l}\text { Forest } \\
\text { district }\end{array}$ & Stand & $\begin{array}{l}\text { Latitude N } \\
\text { (Wgs84) }\end{array}$ & $\begin{array}{l}\text { Longitude } \\
\text { E (Wgs84) }\end{array}$ & $\begin{array}{l}\text { Main } \\
\text { species }\end{array}$ & $\begin{array}{l}\text { Area covered by main } \\
\text { species at site }(\%)\end{array}$ & $\begin{array}{l}\text { Age of } \\
\text { stand } \\
\text { (years) }\end{array}$ & $\begin{array}{l}\text { Forest site } \\
\text { type }\end{array}$ & Soil type \\
\hline $\begin{array}{l}\text { Ostrowiec } \\
\text { Św. }\end{array}$ & 1 & 51,00299 & 21,48032 & $\begin{array}{l}\text { Pinus } \\
\text { sylvestris } \\
\text { L. }\end{array}$ & 70 & 3 & $\begin{array}{l}\text { Mixed Broad- } \\
\text { leaved } \\
\text { Forest }\end{array}$ & $\begin{array}{l}\text { Brunic } \\
\text { Arenosol } \\
\text { (Dystric) }\end{array}$ \\
\hline $\begin{array}{l}\text { Ostrowiec } \\
\text { Św. }\end{array}$ & 2 & 51,00053 & 21,46876 & $\begin{array}{l}\text { Pinus } \\
\text { sylvestris } \\
\text { L. }\end{array}$ & 60 & 36 & $\begin{array}{l}\text { Mixed Broad- } \\
\text { leaved } \\
\text { Forest }\end{array}$ & $\begin{array}{l}\text { Brunic } \\
\text { Arenosol } \\
\text { (Dystric) }\end{array}$ \\
\hline $\begin{array}{l}\text { Ostrowiec } \\
\text { Św. }\end{array}$ & 3 & 50,78952 & 21,5333 & $\begin{array}{l}\text { Quercus } \\
\text { robur } \mathrm{L} .\end{array}$ & 40 & 26 & $\begin{array}{l}\text { Broad-leaved } \\
\text { Forest }\end{array}$ & $\begin{array}{l}\text { Haplic } \\
\text { Cambisol } \\
\text { (Eutric) }\end{array}$ \\
\hline $\begin{array}{l}\text { Ostrowiec } \\
\text { Św. }\end{array}$ & 4 & 50,94104 & 21,52045 & $\begin{array}{l}\text { Quercus } \\
\text { robur L. }\end{array}$ & 60 & 7 & $\begin{array}{l}\text { Broad-leaved } \\
\text { Forest }\end{array}$ & $\begin{array}{l}\text { Haplic } \\
\text { Cambisol } \\
\text { (Eutric) }\end{array}$ \\
\hline $\begin{array}{l}\text { Ostrowiec } \\
\text { Św. }\end{array}$ & 5 & 51,00591 & 21,50341 & $\begin{array}{l}\text { Pinus } \\
\text { sylvestris } \\
\text { L. }\end{array}$ & 50 & 17 & $\begin{array}{l}\text { Mixed Broad- } \\
\text { leaved } \\
\text { Forest }\end{array}$ & $\begin{array}{l}\text { Brunic } \\
\text { Arenosol } \\
\text { (Dystric) }\end{array}$ \\
\hline $\begin{array}{l}\text { Ostrowiec } \\
\text { Św. }\end{array}$ & 6 & 51,00824 & 21,48193 & $\begin{array}{l}\text { Quercus } \\
\text { robur } \mathrm{L} .\end{array}$ & 20 & 21 & $\begin{array}{l}\text { Broad-leaved } \\
\text { Forest }\end{array}$ & $\begin{array}{l}\text { Haplic } \\
\text { Phaeozem }\end{array}$ \\
\hline Lubaczów & 7 & 50,23186 & 23,38211 & $\begin{array}{l}\text { Pinus } \\
\text { sylvestris } \\
\text { L. }\end{array}$ & 60 & 89 & $\begin{array}{l}\text { Broad-leaved } \\
\text { Forest }\end{array}$ & $\begin{array}{l}\text { Haplic } \\
\text { Regosol } \\
\text { (Calcaric) }\end{array}$ \\
\hline Narol & 8 & 50,3356 & 23,26993 & $\begin{array}{l}\text { Pinus } \\
\text { sylvestris } \\
\text { L. }\end{array}$ & 70 & 57 & $\begin{array}{l}\text { Mixed Broad- } \\
\text { leaved } \\
\text { Forest }\end{array}$ & $\begin{array}{l}\text { Rendzic } \\
\text { Leptosol }\end{array}$ \\
\hline Lubaczów & 9 & 50,22318 & 23,36223 & $\begin{array}{l}\text { Pinus } \\
\text { sylvestris } \\
\text { L. }\end{array}$ & 80 & 124 & $\begin{array}{l}\text { Mixed Broad- } \\
\text { leaved } \\
\text { Forest }\end{array}$ & $\begin{array}{l}\text { Haplic } \\
\text { Cambisol } \\
\text { (Dystric) }\end{array}$ \\
\hline Narol & 10 & 50,33357 & 23,2669 & $\begin{array}{l}\text { Pinus } \\
\text { sylvestris } \\
\text { L. }\end{array}$ & 70 & 60 & $\begin{array}{l}\text { Mixed Broad- } \\
\text { leaved } \\
\text { Forest }\end{array}$ & $\begin{array}{l}\text { Rendzic } \\
\text { Leptosol }\end{array}$ \\
\hline $\begin{array}{l}\text { Ostrowiec } \\
\text { Św. }\end{array}$ & 11 & 51,01408 & 21,49013 & $\begin{array}{l}\text { Quercus } \\
\text { robur } \mathrm{L} .\end{array}$ & 40 & 44 & $\begin{array}{l}\text { Broad-leaved } \\
\text { Forest }\end{array}$ & $\begin{array}{l}\text { Haplic } \\
\text { Phaeozem }\end{array}$ \\
\hline $\begin{array}{l}\text { Ostrowiec } \\
\text { Św. }\end{array}$ & 12 & 51,00086 & 21,4665 & $\begin{array}{l}\text { Pinus } \\
\text { sylvestris } \\
\text { L. }\end{array}$ & 50 & 27 & $\begin{array}{l}\text { Mixed broad- } \\
\text { leaved forest }\end{array}$ & $\begin{array}{l}\text { Brunic } \\
\text { Arenosol } \\
\text { (Dystric) }\end{array}$ \\
\hline
\end{tabular}

The study was carried out in the two most representative forest site types for the selected districts: fresh broad-leaved (six sites) and fresh mixed broad-leaved forests (six sites)

sampling pits measuring $0.5 \mathrm{~m}^{2}(1 \times 0.5 \mathrm{~m}$ at a depth at least of $0.5 \mathrm{~m}$ ) were excavated in an overall area of $120 \times 200 \mathrm{~m}$ to assess grub occurrence. The pits were placed according to a grid superimposed over the sample area, and each pit was permanently marked, both physically and with its GPS position. In 2014, six of the 25 sampling pits were re-excavated at each of the 12 sites. All grubs were collected and identified to genus level (Melolontha spp.) in a laboratory using the key presented by Sierpiński (1975). Instars were determined by measuring the width of the head capsule $\left(\mathrm{L}_{1}: 2.6-2.7 \mathrm{~mm}, \mathrm{~L}_{2}: 4.2-4.5 \mathrm{~mm}, \mathrm{~L}_{3}\right.$ : 6.5-6.9 mm) (Śliwa 1993).

The white grubs collected in 2014 were reared separately for six weeks in 120-ml laboratory vials containing sterilised sand and were fed carrot slices. 
Each vial was inspected twice a week for insect mortality. All dead grubs were sterilised in $0.01 \%$ $\mathrm{HgCl}_{2}$ in $70 \%$ ethanol for $1 \mathrm{~min}$. and washed three times in distilled, sterile water. The dead larvae were then incubated at $23{ }^{\circ} \mathrm{C}$ for two weeks in sterile glass Petri dishes, on microscopy glass on wet filter paper. When grub mortality was caused by mycosis, the fungi species responsible were isolated and identified to the genus level using a taxonomy key (Humber 2012) on the basis of morphological characteristics that were determined with a stereoscope (Zeiss, Stemi 2000, Germany). Mortality caused by diseases other than mycosis was not evaluated.

\section{Soil analysis}

General information about the soil characteristics for each stand was taken from soil habitat surveys in the particular forest districts. Soil types and texture were classified in accordance with The Polish Soil Classification (SgP 2011), taking into account the World Reference Base for Soil Resources (FAO 2006).

In addition, in 2014 soil samples were taken from each sampling pit, using a cylindrical soil corer (inner diameter: $55 \mathrm{~mm}$ ), from a depth of 50-150 $\mathrm{mm}$. The samples were placed separately in two sterile $120 \mathrm{ml}$ vials. One vial was used to measure soil $\mathrm{pH}$, and the other to quantify the occurrence of Beauveria spp. Prior to the $\mathrm{pH}$ analyses, all visible plant materials (roots, stems, and leaves) were removed, and the soil samples were air dried and then ground with a rolling pin. The material was then passed through a $2 \mathrm{~mm}$ sieve. In accordance with ISO 10390 (ISO 10390 2015), representative $10 \mathrm{ml}$ samples of the air-dried soil (fraction $<2 \mathrm{~mm}$ ) were potentiometrically measured using a glass electrode in a 1:5 (volume fraction) suspension of soil in water (to measure $\mathrm{pH}$ in $\mathrm{H}_{2} \mathrm{O}$ ), and in $0.01 \mathrm{~mol} \mathrm{l}^{-1}$ calcium chloride solution (to measure $\mathrm{pH}$ in $\mathrm{CaCl}_{2}$ ).

The quantification of Beauveria spp. in soil was carried out as described by Laengle et al. (2005), with modifications. Prior to the analyses, soil samples were subjected to the same protocols as mentioned above, except that they were passed through a $2.5 \mathrm{~mm}$ sieve. Soil samples from each pit were mixed thoroughly and $10 \mathrm{~g}$ of soil was added to $90 \mathrm{ml} 0.01 \%$ (w/v) Tween 80 and shaken at $150 \mathrm{rpm}$ for $60 \mathrm{~min}$. Three Beauveriaselective agar plates (Strasser et al. 1996) were inoculated with $100 \mu$ of undiluted soil suspension and incubated at $23{ }^{\circ} \mathrm{C}$ for 14 days. Fungal colonies were identified as Beauveria spp. if they demonstrated the following two characteristics (Rehner et al. 2011): (1) white, yellowish white, or pale-yellow colour of colonies on Sabouraud agar and (2) conidia aggregated as $<0.1 \mathrm{~mm}$ spherical clusters, white in colour, as determined with a stereoscope. Colonies that were identified as Beauveria spp. were transferred to Sabouraud agar with the use of a sterile inoculating needle to obtain pure cultures. The number of colonies of Beauveria spp. was determined as the number of colony-forming units (CFUs) per gram of dry weight of soil.

\section{DNA isolates and sequencing}

We used sequence comparison of the Bloc Intergenic region to determine Beauveria species affiliation (Rehner et al. 2006), and we used six variable simple sequence repeat (SSR) markers for genotype identification (Mayerhofer et al. 2015) of Beauveria spp. isolates, obtained from the soil samples and from infected cockchafer grubs. DNA of Beauveria spp. isolates was extracted using a Syngen Tissue DNA Mini Kit. Using polymerase chain reaction (PCR) analysis, we amplified the internal transcribed spacer (ITS) region marker with the primers B5.1F/B3.1R (Rehner et al. 2006). The PCR thermal profile was as follows: $95{ }^{\circ} \mathrm{C}$ for $3 \mathrm{~min} ; 40$ cycles at $94{ }^{\circ} \mathrm{C}$ for $30 \mathrm{~s}$, $57{ }^{\circ} \mathrm{C}$ for $30 \mathrm{~s}$, and $72{ }^{\circ} \mathrm{C}$ for $2 \mathrm{~min}$; and a final extension at $72{ }^{\circ} \mathrm{C}$ for $15 \mathrm{~min}$. Amplifications were carried out in $50 \mu \mathrm{l}$ with $3 \mu \mathrm{l}$ of DNA, 25 RedTag Ready Mix (Sigma-Aldrich), $1 \mu$ l of each primer $(10 \mu \mathrm{M})$, and $20 \mu \mathrm{l}$ of PCR water. After visualization of PCR products on agarose gel and purification with a clean-up kit (A\&A Biotechnology), nucleotide sequencing was performed with BigDye Terminator Cycle Sequencing Kit using an ABI 3500 Genetic Analyser (Applied Biosystems; Thermo Fisher Scientific, Inc.) and analysed with Data Collection software ver. 2 (Thermo Fisher Scientific, Inc). Sequences were aligned in BioEdit ver. 7.2.5 (Hall 1999) with reference sequences of two Beauveria species haplotypes.

SSR markers were amplified in two multiplex PCRs: (Bb1F4, Bb2A3, Bb2F8) and (Bb4H9, Bb5F4, $\mathrm{Bb} 8 \mathrm{D6})$ in a total reaction volume of $10 \mu \mathrm{l}$. The reaction volume contained $1 \mu \mathrm{l}$ of DNA, $5 \mu \mathrm{l}$ Multiplex PCR Kit (Qiagen, Germany), $0.2 \mu \mathrm{l}$ of each 
primer (forward and reverse) $(10 \mu \mathrm{M})$, and $2.8 \mu \mathrm{l}$ of PCR water. The PCR thermal profile was as follows: $95{ }^{\circ} \mathrm{C}$ for $15 \mathrm{~min} ; 35$ cycles at $94{ }^{\circ} \mathrm{C}$ for $30 \mathrm{~s}, 58{ }^{\circ} \mathrm{C}$ for $90 \mathrm{~s}$, and $72{ }^{\circ} \mathrm{C}$ for $90 \mathrm{~s}$; and a final extension at $60{ }^{\circ} \mathrm{C}$ for $30 \mathrm{~min}$. Genotyping was performed using an ABI 3500 Genetic Analyser (Applied Biosystems) and allele lengths were scored using GeneMapper ${ }^{\circledR}$ ver. 5 (Thermo Fisher Scientific, Inc.).

Data analysis

Analysis of variance (ANOVA) was performed to test for significant differences between the densities of grubs in 2013 and 2014. Means and SE of Beauveria spp. CFU g ${ }^{-1}$ dry weight soil were calculated for each sampling site. Medians were determined for Beauveria spp. CFU $\mathrm{g}^{-1}$ dry weight soil per soil sample. We used Spearman's rank correlation test to evaluate the relationship between the density of Beauveria spp. and soil $\mathrm{pH}$ range. Logistic regression was used to assess the effects of soil properties on the occurrence of Beauveria spp. and to identify significant variables as predictors of occurrence for given site characteristics. The dependent variable was the absence or presence ( 0 or 1, respectively) of Beauveria spp. For the independent factors, soil $\mathrm{pH}$ and density of white grubs were chosen as quantitative variables, while forest site type, soil type, main pedogenic factor, and similar direction of development of the soil were chosen as qualitative variables. A binomial distribution and logit link function were used. The choice of the optimal model (the best subset) was based on the AIC criterion. The derivation of explanatory variables was based on Wald's statistics and their associated probability values. When evaluating model parameters, the odds ratio (OR) was calculated as a measure of the relationship between the variables. The statistical analyses were performed using the statistical package Statistica 10.0 (2011).

\section{Results}

Density of Melolontha spp. in forest soils

In 2013, the first year of the observation period, the second instar cockchafer larvae $\left(\mathrm{L}_{2}\right)$ were the most common stage in the mass outbreak areas. In 2014, the numbers of cockchafers were similar, and ANOVA showed no statistically significant differences between the two years $\left(\mathrm{F}_{1,350}=0.0002, p=0.9883\right)$. In 2014, $91 \%$ of cockchafers were third instar larvae $\left(\mathrm{L}_{3}\right)$. Melolontha spp. densities varied among the sites from 0 to $16 \mathrm{~L}_{3}$ per $0.5 \mathrm{~m}^{2}$. There were only two sites (sites 5 and 6) at which cockchafer grubs were not found. At $50 \%$ of the sites, the population density of Melolontha spp. was higher than the threshold level for economic losses defined in Instrukcja ochrony lasu (2012) (i.e., 3 $L_{2}$ or $L_{3}$ per $0.5 \mathrm{~m}^{2}$ for forest site types where the research was performed) (Fig. 1).

In 2014, the grubs were reared in sterile sand and observed in the laboratory. After six weeks, 76 out of 232 cockchafers had died. Entomopathogenic fungi caused the death of only four of these individuals: three grubs were infected with Beauveria spp., and one with Metarhizium spp.

Soil analyses

Soil samples revealed the presence of Beauveria spp. at ten of the 12 sites. At sites 4 and 8, Beauveria spp. were not detected (Fig. 2). At the other sites, Beauveria densities reached up to $2.7 \times 10^{4} \mathrm{CFU} \mathrm{g}^{-1}$ dry weight soil. However, at each site, there were individual samples in which Beauveria colonies were not detected. Only $33.3 \%$ of all soil samples contained Beauveria spp.

According to the classification of soil $\mathrm{pH}$ ranges (United States Department of Agriculture Natural Resources Conservation Service), the soil $\mathrm{pH}$ ranged from extremely acidic (4.3) to moderately alkaline (7.4). In general, very strongly acidic soils predominated ( $\mathrm{pH}$ of 4.5 to 5.0) (Table 2). We found a positive correlation between $\mathrm{pH}$ ranges both in $\mathrm{H}_{2} \mathrm{O}$ and in $\mathrm{CaCl}_{2}$ and Beauveria densities from the same sampling pits, with $\alpha=0.05$ level of significance. The Spearman's rank correlation coefficients were as follows: $r_{\mathrm{s}}=0.1908(p=0.0049)$ and $\mathrm{r}_{\mathrm{s}}=0.2291$ $(p=0.0007)$.

\section{Logistic regression}

On the basis of Akaike criteria, the best subset among six candidate predictors were soil type and soil $\mathrm{pH}$ (Table 3). The results of Hosmer-Lemeshow goodness of fit test of the final model, choosing nine groups $(\mathrm{g}=9)$, were as follows: $\chi^{2}=8.4217 \quad(d f=7$, $p=0.2968$ for the model with $\mathrm{pH}$ in $\mathrm{H}_{2} \mathrm{O}$ as an 
Fig. 1 Number of cockchafer white grubs (mean $\pm \mathrm{SE}$ ) (Melolontha spp.) per sampling pit $(1 \times 0.5 \mathrm{~m}$ at a depth of at least $0.5 \mathrm{~m}$ ) at forest sites in two consecutive study years. Means were determined from 25 pits excavated in 2013 and six pits reexcavated in 2014 per site. Pits were placed using a grid superimposed over the sample area. Site numbers correspond to site numbers in Table 1

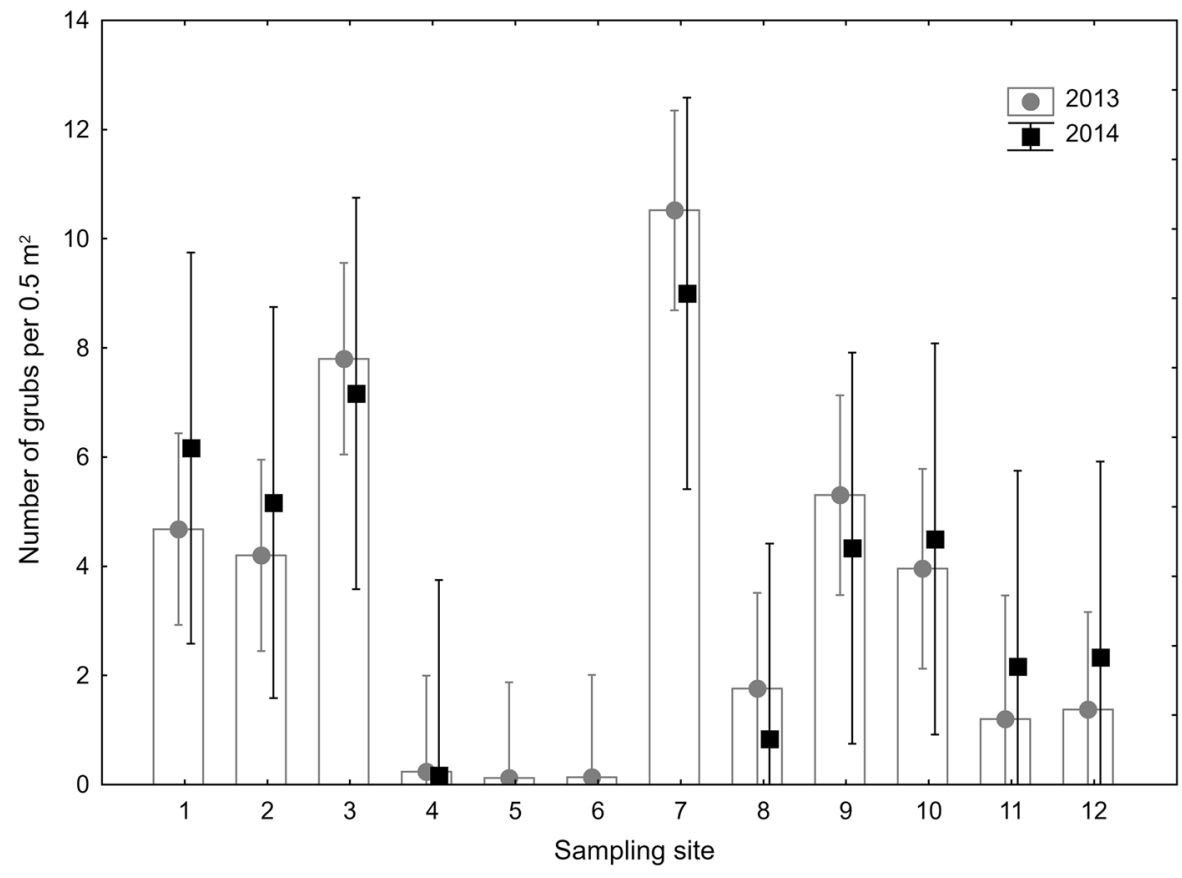

Fig. 2 Density of Beauveria spp. (CFU g ${ }^{-1}$ dry weight soil) in forest stands (mean $\pm \mathrm{SE}$ ).

Beauveria spp. densities were determined at six sampling pits per site and for three replicates per soil sample. Y-axis values are shown in a logarithmic scale. Site numbers correspond to site numbers in Table 1

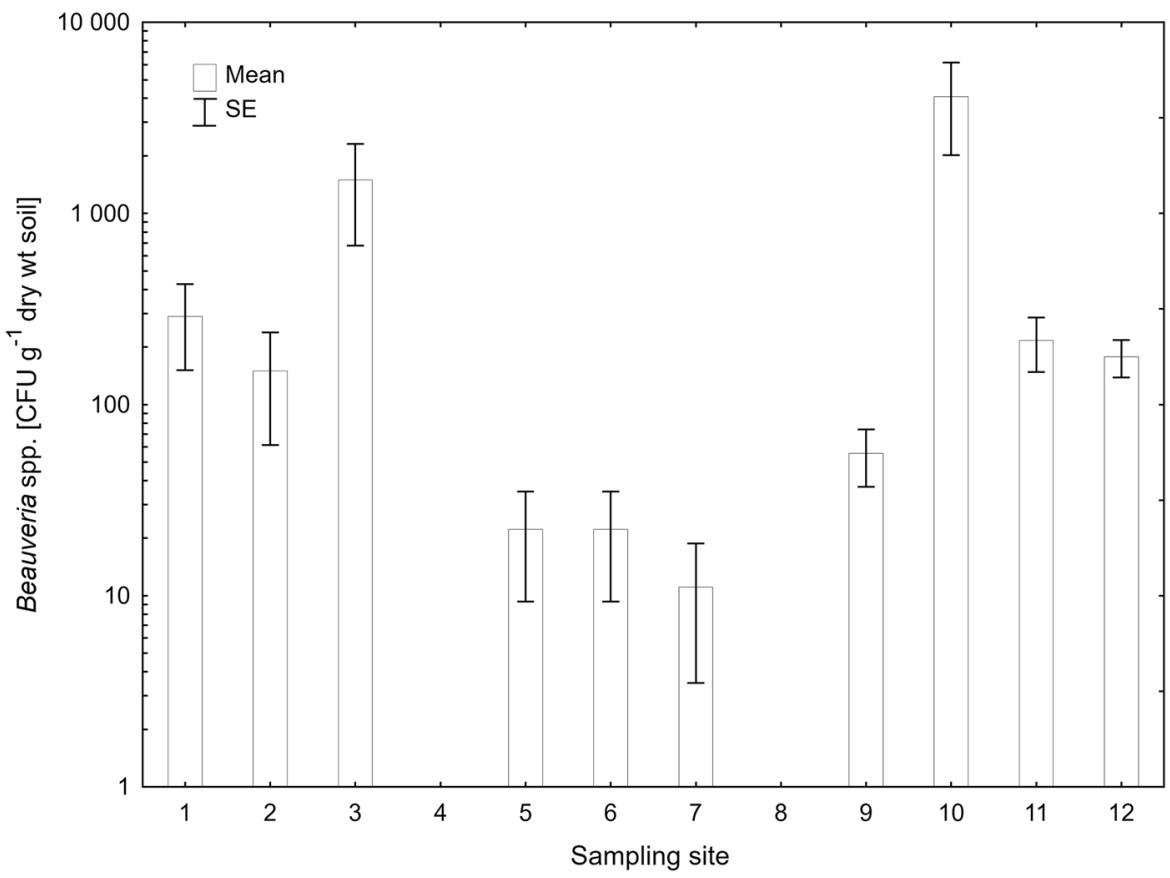

explanatory variable $)$ and $\chi^{2}=7.5499 \quad(d f=7$, $p=0.3739$ for the model with $\mathrm{pH}$ in $\mathrm{CaCl}_{2}$ as an explanatory variable), which indicates that there is no evidence of poor fit (there are no differences between the observed and predicted values of the dependent variable). The model correctly predicts the presence of
Beauveria spp. in $81 \%$ of cases and their absence in $69 \%$ of cases for the model with $\mathrm{pH}$ in $\mathrm{H}_{2} \mathrm{O}$, and $78 \%$ and $71 \%$ respectively, for the model with $\mathrm{pH}$ in $\mathrm{CaCl}_{2}$.

The evaluation of the model parameters showed that the presence of Beauveria spp. in soil is most affected by soil $\mathrm{pH}$ (Table 3 ), and that an increase in 
Table 2 Soil $\mathrm{pH}$ values, numbers of cockchafer grubs (Melolontha spp.), and density of Beauveria spp. at forest sites, as determined at six sampling pits per site. Values of

\begin{tabular}{|c|c|c|c|c|c|c|c|c|c|c|c|c|}
\hline \multirow[t]{2}{*}{ Site $^{a}$} & \multicolumn{3}{|c|}{$\mathrm{pH}$ in $\mathrm{H}_{2} \mathrm{O}$} & \multicolumn{3}{|c|}{$\mathrm{pH}$ in $\mathrm{CaCl}_{2}$} & \multicolumn{3}{|c|}{$\begin{array}{l}\text { Number of grubs per } 0.5 \mathrm{~m}^{2} \\
\text { sampled soil }\end{array}$} & \multicolumn{3}{|c|}{$\begin{array}{l}\text { Density of Beauveria spp. (CFU g }{ }^{-1} \text { dry } \\
\text { wt soil) }\end{array}$} \\
\hline & Min & Median & Max & Min & Median & Max & Min & Median & Max & Min & Median & Max \\
\hline 1 & 4.8 & 5.1 & 5.4 & 3.9 & 4 & 4.2 & 0 & 7 & 12 & 0 & 50 & 2,300 \\
\hline 2 & 4.7 & 4.75 & 5.3 & 3.6 & 3.8 & 4.3 & 0 & 4.5 & 7 & 0 & 0 & 1,500 \\
\hline 3 & 5 & 5.3 & 5.9 & 4.1 & 4.4 & 4.6 & 1 & 5 & 15 & 0 & 0 & 10,300 \\
\hline 4 & 4.6 & 4.7 & 5 & 3.7 & 3.85 & 4.1 & 0 & 0 & 1 & 0 & 0 & 0 \\
\hline 5 & 4.5 & 4.7 & 4.9 & 3.7 & 3.85 & 4.1 & 0 & 0 & 0 & 0 & 0 & 200 \\
\hline 6 & 4.4 & 4.9 & 5.1 & 3.4 & 4 & 4.3 & 0 & 0 & 0 & 0 & 0 & 200 \\
\hline 7 & 4.4 & 4.5 & 4.8 & 3.7 & 3.75 & 3.9 & 2 & 8 & 15 & 0 & 0 & 100 \\
\hline 8 & 4.4 & 4.95 & 6.1 & 3.6 & 3.95 & 5.4 & 0 & 1 & 3 & 0 & 0 & 0 \\
\hline 9 & 4.3 & 4.55 & 4.8 & 3.6 & 3.8 & 4.1 & 0 & 3 & 9 & 0 & 0 & 200 \\
\hline 10 & 6.8 & 8 & 8.1 & 6.3 & 7.3 & 7.4 & 0 & 4.5 & 8 & 0 & 300 & 27,000 \\
\hline 11 & 4.4 & 4.7 & 4.9 & 3.7 & 3.85 & 4.1 & 0 & 1 & 8 & 0 & 100 & 800 \\
\hline 12 & 4.4 & 4.7 & 4.9 & 3.7 & 3.85 & 4 & 0 & 1 & 3 & 0 & 100 & 600 \\
\hline
\end{tabular}

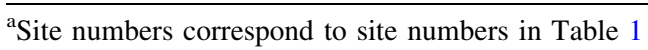

$\mathrm{pH}$ of one unit was associated with an increased chance of Beauveria spp. occurrence by 14.6 (OR) (for the model with $\mathrm{pH}$ in $\mathrm{H}_{2} \mathrm{O}$ ). The logistic regression model also showed that Beauveria spp. occurrence varied with soil type. The probability of Beauveria occurrence was highest in Albic Luvisol soil and lowest in Rendzic Leptosols and Haplic Cambisols (Eutric) (Fig. 3).

DNA sequence alignment

The number of Beauveria spp. isolates collected from different sites varied, ranging from 0 (at sites 4,7 , and 8 ) to six isolates per site (at site 10). The sequence of ITS markers of Beauveria spp. was 1385 bp long. From 30 samples of Beauveria spp., we obtained three haplotypes: two from B. pseudobassiana (Bals.) Vuill. and one from $B$. brongniartii. We detected length differences between haplotypes from these two species (three INDELs in total). Two haplotypes of internal transcribed spacer B locus were identical to sequences deposited in the GeneBank database, from Rehner et al. (2011): HQ880728 (B. pseudobassiana) and HQ880713 (B. brongniartii). One of the sequences for $B$. pseudobassiana was recorded for the first time in the present study (MG029116) and
Beauveria spp. colony-forming units (CFUs) were determined as three replicates per soil sample 
Table 3 Optimal model of logistic regression predicting the occurrence of Beauveria spp. as a function of soil characteristics at study sites (two independent analyses for $\mathrm{pH}$ in $\mathrm{H}_{2} \mathrm{O}$ and $\mathrm{pH}$ in $\mathrm{CaCl}_{2}$ )

\begin{tabular}{|c|c|c|c|c|c|c|c|c|c|c|c|}
\hline $\begin{array}{l}\text { Independent } \\
\text { variable }\end{array}$ & df & $\begin{array}{l}\text { Wald's } \\
\text { stat. }\end{array}$ & $p$ & Level & Coef. & SE & $\begin{array}{l}\text { Wald's } \\
\text { stat. }\end{array}$ & $p$ & OR & $\begin{array}{l}-95 \% \\
\text { CI }\end{array}$ & $\begin{array}{l}+95 \% \\
\text { CI }\end{array}$ \\
\hline Intercept & 1 & 7.660 & 0.006 & - & -13.692 & 4.947 & 7.660 & 0.006 & - & - & - \\
\hline \multirow[t]{5}{*}{ soil type } & 5 & 12.103 & 0.033 & $\begin{array}{l}\text { Brunic Arenosol } \\
\text { (Dystric) }\end{array}$ & 1.479 & 0.577 & 6.567 & 0.010 & 4.389 & 1.416 & 13.599 \\
\hline & & & & $\begin{array}{l}\text { Haplic Cambisol } \\
\quad \text { (Eutric) }\end{array}$ & -1.783 & 0.808 & 4.865 & 0.027 & 0.168 & 0.034 & 0.819 \\
\hline & & & & Albic Luvisol & 1.690 & 0.712 & 5.628 & 0.018 & 5.418 & 1.342 & 21.873 \\
\hline & & & & $\begin{array}{l}\text { Haplic Regosol } \\
\text { (Calcaric) }\end{array}$ & 0.785 & 0.938 & 0.700 & 0.403 & 2.191 & 0.348 & 13.775 \\
\hline & & & & Rendzic Leptosol & -3.628 & 1.767 & 4.219 & 0.040 & 0.027 & 0.001 & 0.862 \\
\hline $\mathrm{pH} \mathrm{H} \mathrm{H}_{2} \mathrm{O}$ & 1 & 7.556 & 0.006 & - & 2.679 & 0.975 & 7.556 & 0.006 & 14.571 & 2.156 & 98.498 \\
\hline Intercept & 1 & 6.523 & 0.011 & - & -17.010 & 6.660 & 6.523 & 0.011 & - & - & - \\
\hline \multirow[t]{5}{*}{ soil type } & 5 & 11.388 & 0.044 & $\begin{array}{l}\text { Brunic Arenosol } \\
\text { (Dystric) }\end{array}$ & 2.266 & 0.836 & 7.348 & 0.007 & 9.643 & 1.873 & 49.64 \\
\hline & & & & $\begin{array}{l}\text { Haplic Cambisol } \\
\quad \text { (Eutric) }\end{array}$ & -1.455 & 0.817 & 3.169 & 0.075 & 0.233 & 0.047 & 1.156 \\
\hline & & & & Albic Luvisol & 2.235 & 0.912 & 6.003 & 0.014 & 9.346 & 1.564 & 55.839 \\
\hline & & & & $\begin{array}{l}\text { Haplic Regosol } \\
\quad \text { (Calcaric) }\end{array}$ & 1.305 & 1.121 & 1.356 & 0.244 & 3.689 & 0.410 & 33.199 \\
\hline & & & & Rendzic Leptosol & -6.241 & 3.048 & 4.193 & 0.041 & 0.002 & $<0.001$ & 0.786 \\
\hline $\mathrm{pH} \mathrm{CaCl} 2$ & 1 & 6.491 & 0.011 & - & 3.982 & 1.563 & 6.491 & 0.011 & 53.612 & 2.505 & 1147.399 \\
\hline
\end{tabular}

The output provides the coefficients for explanatory variables and their levels. The Haplic Cambisol (Dystric) was chosen as a reference level for soil types $(\mathrm{SE}=$ standard error, $\mathrm{CI}=$ confidence intervals, boldface text indicates statistical significance at $\alpha=0.05, \mathrm{OR}=$ odds ratio)

genotypes were represented by a larger number (two to five). The highest number of different genotypes (five genotypes) was found at site 10 . The most common genotypes, C and I, were found at two (sites 1 and 12) and three (sites 3,11, and 12) different sites, respectively (Table 4).

\section{Discussion}

Numerous studies have demonstrated the close relationship between $B$. brongniartii and Melolontha spp. (Keller et al. 2003; Kessler et al. 2004). B. brongniartii has been reported to be a highly host-specific fungus that exclusively infects Melolontha spp. under natural conditions in Central Europe (Kessler et al. 2004; Neuvéglise et al. 1994). In Switzerland, Keller et al. (2003) demonstrated the natural occurrence of $B$. brongniartii and $M$. melolontha together in meadow soils. During a forest cockchafer outbreak in southwest Germany, Trzebitzky (1996) found that more than $50 \%$ of the natural infections of $M$. hippocastani grubs in forest soils were caused by $B$. brongniartii. In contrast, during an outbreak of the common cockchafer (with a grub population density of 0 to 72 per $\mathrm{m}^{2}$ ) in Valle D'Aosta, Italy, only two larvae were affected by mycosis in one year (Cravanzola et al. 1996). Similarly, in the present study, only $1.3 \%$ of cockchafer grubs were infected by $B$. brongniartii. The low levels of infection of cockchafer grubs and maintenance of stable populations of larval cockchafers in the present study can be partly explained by the high resistance of older $\left(\mathrm{L}_{2}\right.$ or $\left.\mathrm{L}_{3}\right)$ instar larvae, which were dominant during the study period. Sukovata et al. (2015) tested the efficacy of a biocide product against Melolontha grubs and observed a higher resistance rate and lower mortality rate among $\mathrm{L}_{3}$ grubs compared with the $\mathrm{L}_{1}$ and $\mathrm{L}_{2}$ instar larvae at the same biocide concentration. Kessler (2004) found that the age and origin of 
Fig. 3 Predicted and observed probability $[ \pm$ confidence intervals (CI)] of Beauveria spp. occurrence depending on forest soil types, using the optimal model of logistic regression

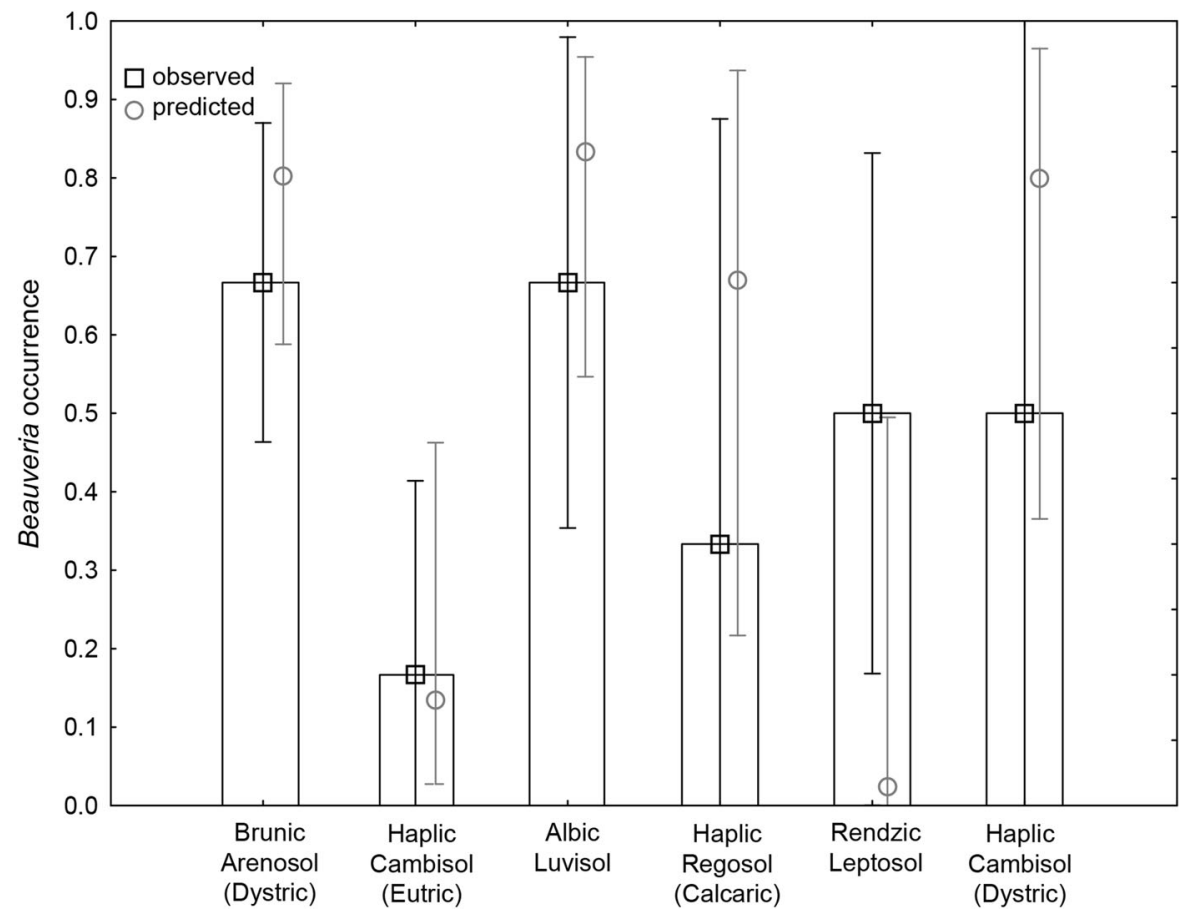

Melolontha larvae influence the efficacy of BCA as much as does the virulence of the spore types.

The low level of infection caused by $B$. brongniartii in forest soils can be further explained by the $\mathrm{pH}$ conditions, which were suboptimal for the growth of Beauveria spp. According to Enkerli et al. (2001), sustainable cockchafer control can be achieved when fungal density reaches $1 \times 10^{3}-1 \times 10^{4} \mathrm{CFU} \mathrm{g}^{-1}$. Densities at this level were found at sites 1, 2, 3, and 10 , but the fungus was parasitic only at sites 2 and 10 . Notably, site 10 was characterised by the highest soil $\mathrm{pH}$ ranges. The importance of $\mathrm{pH}$ in Beauveria development and pathogenicity in the present study was reflected by the positive relationship between the $\mathrm{pH}$ ranges and fungal densities (Spearman's rank correlation). Logistic regression analyses confirmed that $\mathrm{pH}$ ranges, supported by soil type, were significant predictive variables for the occurrence of Beauveria spp. Strong soil acidity was responsible for the absence of these hyphomycetous fungi. An increase in the $\mathrm{pH}$ by one unit resulted in a 14.6-fold higher probability of Beauveria occurrence within the studied $\mathrm{pH}$ ranges.

Our findings confirm the results of previous studies. According to Padmavathi et al. (2003), a pH of 3 was toxic to all tested isolates of B. bassiana (closely related to $B$. brongniartii). Conidia germinated at this $\mathrm{pH}$, but growth was completely inhibited. Qazi (2008) noted that differences in the germination capability of B. bassiana conidia under differing substrate $\mathrm{pH}$ conditions were explained by the specific optimal $\mathrm{pH}$ values required for the expression of proteases produced by the fungus. Overly acidic (or overly alkaline) reactions can adversely affect conidia germination in B. brongniartii, which may explain our observation of hindered mycosis in cockchafer grub populations.

Considering the isolation of entomopathogenic fungi (including Beauveria) from natural and cultivated areas, Quesada-Moraga et al. (2007) detected a narrow $\mathrm{pH}$ that was optimum for B. bassiana, with $52.9 \%$ of samples falling within 8.0-8.5. Karthikeyan et al. (2008) confirmed that the optimal soil $\mathrm{pH}$ for Beauveria spp. development ranges from 6 to 8 . Moreover, these fungi typically occur in lowland soils with neutral or alkaline pH (Medo and Cagán 2011) and are detected more frequently in natural forest soils than in cultivated ones (Shin et al. 2013). Taking into account that our soil samples were representative of most Polish forest $\mathrm{pH}$ ranges (acidic and very acidic soils make up $50 \%$ of Poland's area), our results demonstrate that strong soil acidity in forests provides 


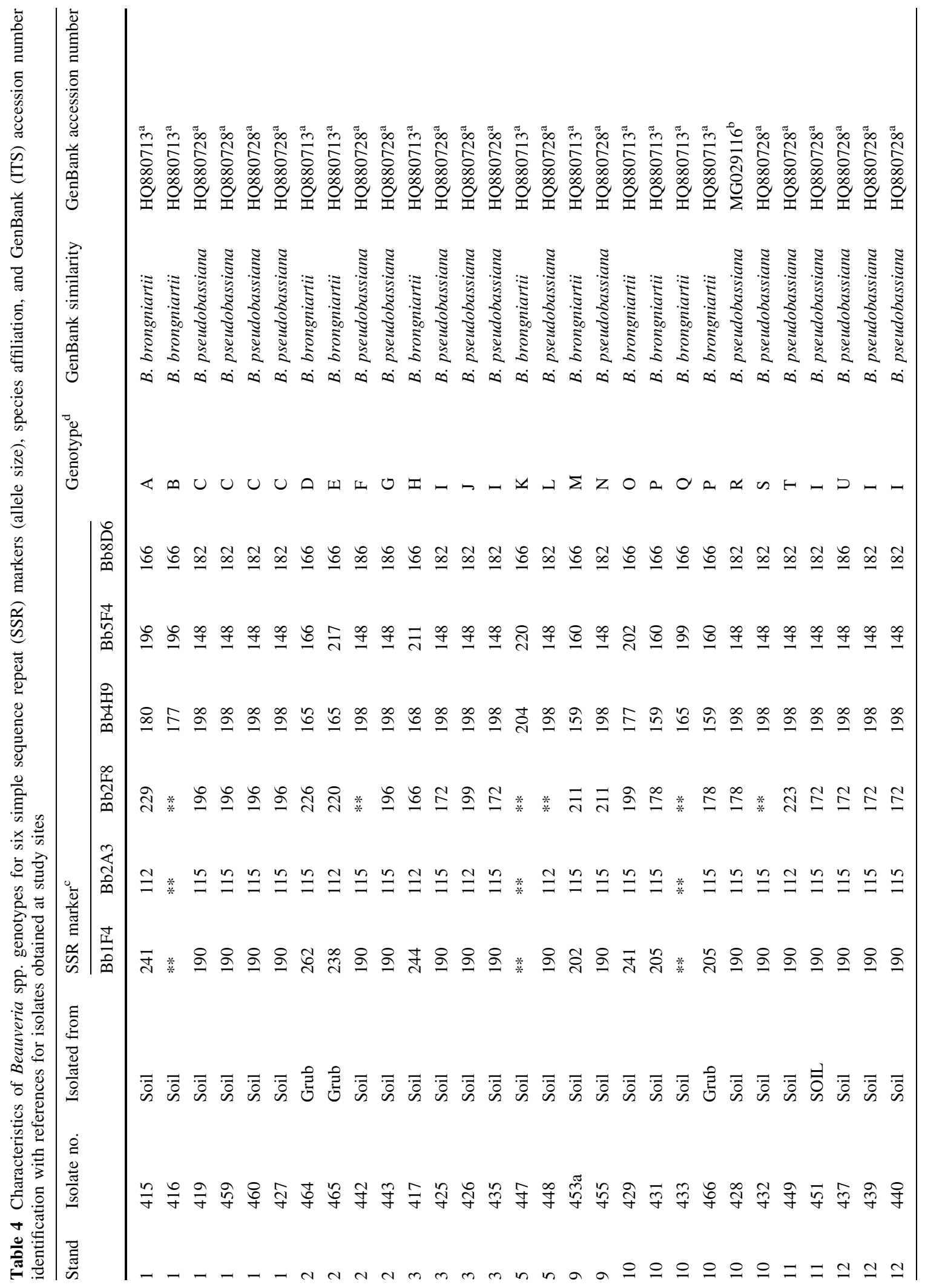




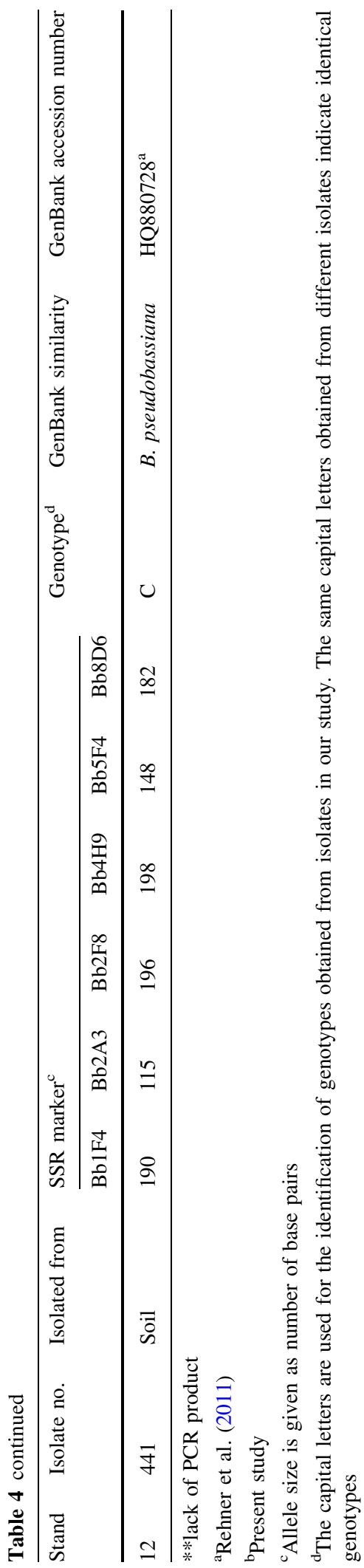

a suboptimal environment for the development of Beauveria spp.

Our study area encompassed several types of soil, including extremely gravelly and/or stony Leptosols, sandy Arenosols, soils of increasing clay content such as Cambisols, and high-activity clays throughout the argic horizon in the Luvisols. The probability of Beauveria occurrence was highest in the latter types of soil. Many previous studies (Mietkiewski et al. 1997; Milner 1989; Quesada-Moraga et al. 2007) reported that the occurrence of entomopathogenic fungi is associated with soils with high clay content. This may be because leaching of the inoculum is correlated with the water infiltration value of soils, which is higher in sandy soils than in finer-textured soils (Storey and Gardner 1988). Some studies also suggested that a high clay content in soil enhances the abundance and persistence of many insect pathogenic fungi because conidia are adsorbed onto clay particles (Inglis et al. 2001; Studdert et al. 1990). Therefore, the soil type is another source of information (in addition to $\mathrm{pH}$ ranges) that indicates the potential occurrence and persistence of entomopathogenic fungi in the forest environment.

Beauveria spp. isolates were detected at more than $80 \%$ of sites and in $33.3 \%$ of soil samples, comparable to recovery rates from other countries with cold/humid temperate climates. According to Vänninen (1996), Beauveria were detected in $19.8 \%$ of soil samples from Finish soils. Typical recovery rates were $18 \%$ in the Pacific Northwest (Bruck 2004). Based on sequence alignment in the present study, three different haplotypes of Beauveria spp. were identified in forest sites: two haplotypes belonging to $B$. pseudobassiana species and one to B. brongniartii. $B$. brongniartii, an important species of entomopathogenic fungus that is indigenous to the study area, was present in 11 of 30 isolates, and ten different genotypes were detected in the samples. By comparison, 41 different $B$. brongniartii genotypes were detected among 63 isolates from two sites in Switzerland (Enkerli et al. 2001) and 13 B. brongniartii genotypes were detected from 92 isolates from the Tyrol region (Mayerhofer et al. 2015). In the present study, B. brongniartii was identified in soils in $41 \%$ of forest sites (five sites) and was also isolated from cockchafer grubs in two sites.

In summary, only two species of Beauveria were found in the forest soils we sampled: $B$. 
pseudobassiana and B. brongniartii. B. brongniartii, an important natural pathogen of cockchafers, did not occur frequently and its density was often below the threshold value for the effective infection of cockchafer grubs. We determined that Beauveria genotypes are sensitive to soil $\mathrm{pH}$ and soil types in forest environments. Our results suggest that the B. brongniartii genotype isolated from cockchafers from forest soils can expand the pool of potential BCAs in the forest environment. However, additional studies are needed to explore the genotypes of virulence and optimal pH conditions for Beauveria spp. for use as BCAs.

Acknowledgements This research was financially supported by the Forest Research Institute (Project No. 240226). We thank our colleague from the Forest Research Institute, Szymon Krajewski for assistance during field data collection.

Author contributions All authors have read and approved the final version of the manuscript. All authors have agreed to authorship and the order of authorship for this manuscript; and all authors have the appropriate permissions and rights to the reported data.

\section{Compliance with ethical standards}

Conflicts of interest The authors declare no conflict of interest.

Open Access This article is distributed under the terms of the Creative Commons Attribution 4.0 International License (http:// creativecommons.org/licenses/by/4.0/), which permits unrestricted use, distribution, and reproduction in any medium, provided you give appropriate credit to the original author(s) and the source, provide a link to the Creative Commons license, and indicate if changes were made.

\section{References}

Blaisinger P (1988) Rapport sur le hanneton en France. Table ronde sur Melolontha melolontha, Saint-Vincent, pp 7-11

Bruck DJ (2004) Natural occurrence of entomopathogens in Pacific Northwest nursery soils and their virulence to the black vine weevil, Otiorhynchus sulcatus (F.) (Coleoptera: Curculionidae). Environ Entomol 33:1335-1343

Canfora L, Malusà E, Tkaczuk C, Tartanus M, Łabanowska BH, Pinzari F (2016) Development of a method for detection and quantification of $B$. brongniartii and B. bassiana in soil. Sci Rep 6:96-100

Cravanzola F, Piatti P, Ozino OI, Bondaz F, Vallet S (1996) Occurrence of the entomopathogenic fungus Beauveria brongniartii in the soil of Valle d'Aosta and infestation level of Melolontha melolontha. IOBC/WPRS Bull 19:59-64

Directive 2009/128/EC of the European Parliament and of the Council of 21 October 2009 establishing a framework for Community action to achieve the sustainable use of pesticides: http://data.europa.eu/eli/dir/2009/128/oj. Accessed 5 Feb 2019

Dolci P, Guglielmo F, Secchi F, Ozino OI (2006) Persistence and efficacy of Beauveria brongniartii strains applied as biocontrol agents against Melolontha melolontha in the Valley of Aosta (northwest Italy). J App Microbiol 100:1063-1072

Enkerli J, Widmer F, Gessler C, Keller S (2001) Strain-specific microsatellite markers in the entomopathogenic fungus Beauveria brongniartii. Mycol Res 105:1079-1087

Enkerli J, Widmer F, Keller S (2004) Long-term field persistence of Beauveria brongniartii strains applied as biocontrol agents against European cockchafer larvae in Switzerland. Biol Control 29:115-123

Fodor A, Mathe A, Furgani G, Klein MG, Inantsi F (2005) First steps toward biological control of Melolontha melolontha by entomopathogenic nematodes in Hungary. IOBC/ WPRS Bull 28:29

Galani G (1988) Cultivation of some entomopathogenic fungi in liquid media with various initial $\mathrm{pH}$ values. Analele Institutului de Cercetari pentru Protectia Plantelor 21:45-54

Goble TA, Costet L, Robene I, Nibouche S, Rutherford RS, Conlong DE, Hill MP (2012) Beauveria brongniartii on white grubs attacking sugarcane in South Africa. J Invertebr Pathol 111:225-236

Hall TA (1999) BioEdit: a user-friendly biological sequence alignment editor and analysis program for Windows 95/98/ NT. Nucl Acids Symp Ser 41:95-98

Humber RA (2012) Identification of entomopathogenic fungi. In: Lacey LA (ed) Manual of techniques in invertebrate pathology. Academic Press, San Diego, pp 151-187

Imoulan A, Hussain M, Kirk PM, El Meziane A, Yao Y-J (2017) Entomopathogenic fungus Beauveria: host specificity, ecology and significance of morpho-molecular characterization in accurate taxonomic classification. J Asia Pac Entomol 20:1204-1212

Inglis GD, Goettel MS, Butt T, Strasser H (2001) Use of hyphomycetous fungi for managing insect pests. In: Butt TM, Jackson CW, Magan N (eds) Fungi as biocontrol agents: progress, problems and potential. CABI Publishing, Wallingford, pp 23-70

Instrukcja ochrony lasu (2012) Tom II. CILP, Warsaw

Jackson MA, Dunlap CA, Jaronski ST (2010) The ecological considerations in producing and formulating fungal entomopathogens in insect biocontrol. BioControl 55:129-145

Karthikeyan A, Shanthi V, Nagasathya A (2008) Effect of different media and $\mathrm{pH}$ on the growth of Beauveria bassiana and its parasitism on leaf eating caterpillars. Res J Agric Biol Sci 4:117-119

Keller E (1988) Entwicklung der maikäferpopulation in kanton Thurgau (Schweitz). Table ronde sur Melolontha melolontha, Saint-Vincent, pp 16-19

Keller SC, Schweizer C, Keller E, Brenner H (1997) Control of white grubs (Melolontha melolontha L.) by treating adults with the fungus Beauveria brongniartii. Biocontrol Sci Technol 7:105-116 
Keller S, Kessler P, Schweizer C (2003) Distribution of insect pathogenic soil fungi in Switzerland with special reference to Beauveria brongniartii and Metarhizium anisopliae. BioControl 48:307-319

Kessler P (2004) Influence of soil factors on virulence, growth and survival of the fungus Beauveria brongniartii, a specific biocontrol agent of the European cockchafer (Melolontha melolontha). Doctoral thesis. ETH Zürich. https://doi.org/10.3929/ethz-a-004709553

Kessler P, Matzke H, Keller S (2003) The effect of application time and soil factors on the occurrence of Beauveria brongniartii applied as a biological control agent in soil. J Invertebr Pathol 84:15-23

Kessler P, Enkerli J, Schweize C, Keller S (2004) Survival of Beauveria brongniartii in the soil after application as a biocontrol agent against the European cockchafer Melolontha melolontha. BioControl 49:563-581

Kliczkowska A, Zielony R, Czępińska-Kamińska D, Kowalkowski A, Sikorska E, Krzyżanowski A, Cieśla A, Czerepko J (2003) Siedliskowe podstawy hodowli lasu. Dyrekcja Generalna Lasów Państwowych, Warsaw

Lacey LA, Grzywacz D, Shapiro-Ilan DI, Frutos R, Brownbridge M, Goettel MS (2015) Insect pathogens as biological control agents: back to the future. J Invertebr Pathol 132:1-41

Laengle T, Pernfuss B, Seger C, Strasser H (2005) Field efficacy evaluation of Beauveria brongniartii against Melolontha melolontha in potato cultures. Sydowia 57:54-93

Li Z, Li C, Huang B, Fan M (2001) Discovery and demonstration of teleomorph of Beauveria bassiana (Bals.) Vuill., an important entomogenous fungus. Chin Sci Bull 46:751753

Malinowski H, Woreta D, Stocki J (1996) Problems of the occurrence and management of Melolontha in Polish forestry. IOBC/WPRS Bull 19:21-26

Mayerhofer J, Enkerli J, Zelger R, Strasser H (2015) Biological control of the European cockchafer: persistence of Beauveria brongniartii after long-term applications in the Euroregion Tyrol. BioControl 60:617-629

Mazid S, Rajkhowa RC, Kalita JC (2011) A review on the use of biopesticides in insect pest management. Int $\mathrm{J}$ Sci Adv Technol 1:169-178

Medo J, Cagáň L' (2011) Factors affecting the occurrence of entomopathogenic fungi in soils of Slovakia as revealed using two methods. Biol Control 59:200-208

Meyling NV, Eilenberg J (2007) Ecology of the entomopathogenic fungi Beauveria bassiana and Metarhizium anisopliae in temperate agroecosystems: potential for conservation biological control. Biol Control 43:145-155

Mietkiewski R, Pell JK, Clark SJ (1997) Influence of pesticide use on the natural occurrence of entomopathogenic fungi in arable soils in the UK: field and laboratory comparisons. Biocontrol Sci Technol 7:565-575

Milner RJ (1989) Ecological considerations in the use of $M e$ tarhizium for control of soil-dwelling pests. In: Robertson LN, Allsopp PG (eds), In: Proceedings of a soil-invertebrate workshop. Queensland Department of Primary Industries conference and workshop series QC 89004, Indooroopilly, Queensland, pp 10-13

Neuvéglise C, Brygoo Y, Vercambre B, Riba G (1994) Comparative analysis of molecular and biological characteristics of strains of Beauveria brongniartii isolated form insects. Mycol Res 98:322-328

Niemczyk M (2015) Ryzyko masowego występowania pędraków chrabąszczy (Melolontha spp.) w strefie ekotonowej drzewostanów dojrzałych na terenie Nadleśnictwa Lubaczów. Sylwan 159:326-335

Niemczyk M, Karwański M, Grzybowska U (2017) Effect of environmental factors on occurrence of cockchafers (Melolontha spp.) in forest stands. Balt For 23:334-341

Padmavathi J, Uma Devi K, Uma Maheswara Rao C (2003) The optimum and tolerance $\mathrm{pH}$ range is correlated to colonial morphology in isolates of the entomopathogenic fungus Beauveria bassiana - a potential biopesticide. World J Microbiol Biotechnol 19:469-477

Qazi SS (2008) Regulatory role of ambient $\mathrm{pH}$ in the expression of pathogenicity determinant gene products of Beauveria bassiana and Metarhizium anisopliae. $\mathrm{PhD}$ thesis, University of Saskatchewan, Canada https://www.collec tionscanada.gc.ca/obj/s4/f2/dsk3/SSU/TC-SSU-03112008 114358.pdf. Accessed 5 Feb 2019

Quesada-Moraga E, Navas-Cortés JA, Maranhao EA, OrtizUrquiza A, Santiago-Alvarez C (2007) Factors affecting the occurrence and distribution of entomopathogenic fungi in natural and cultivated soils. Mycol Res 111:947-966

Rehner SA, Posada F, Buckley EP, Infante F, Castillo A, Vega FE (2006) Phylogenetic origins of African and neotropical Beauveria bassiana s.l. pathogens of the coffee berry borer, Hypothenemus hampei. J Invertebr Pathol 93:11-21

Rehner SA, Minnis AM, Sung G-H, Luangsaard JJ, Devotto L, Humber RA (2011) Phylogeny and systematics of the anamorphic, entomopathogenic genus Beauveria. Mycologia 103:1055-1073

Sanzhimitupova RD (1980) Effect of the $\mathrm{pH}$ of the medium on the growth and development of the causal agent of mycosis of the sea-buckthorn moth (Gelechia hippophaella Schrk.). Izvestiya Sibirskogo Otdeleniya Akademii Nauk SSSR Biol 15:39-41

Scheepmaker JWA, Butt TM (2010) Natural and released inoculum levels of entomopathogenic fungal biocontrol agents in soil in relation to risk assessment and in accordance with EU regulations. Biocontrol Sci Technol 20:503-552

Sharma S, Agarwal GP, Rajak RC (1992) Effect of temperature, $\mathrm{pH}$ and light on toxin production by Beauveria bassiana (Bal) Vuill. Indian J Exp Biol 30:918-919

Shin TY, Lee WW, Ko SH, Choi JB, Bae SM, Choi JY, Bae SM, Choi JY, Lee KS, Ye YH, Jin BR, Woo SD (2013) Distribution and characterisation of entomopathogenic fungi from Korean soils. Biocontrol Sci Technol 23:288-304

Sierpińska A (2008) Spostrzeżenia na temat ekologii chrabąszcza majowego (Melolontha melolontha L.) i chrabąszcza kasztanowca (Melolontha hippocastani Fabr.) na podstawie obserwacji przeprowadzonych w 2007 roku w Nadleśnictwie Piotrków. Prog Plant Prot/Postępy w Ochronie Roślin 48:956-965

Sierpińska A, Popowska-Nowak E, Bednarek A (2015) Beauveria brongniartii Sacc. (Petch) against Melolontha spp. white grubs in forest nurseries with different soil $\mathrm{pH}$. Folia For Pol Ser A 57:210-217

Sierpiński Z (1975) Ważniejsze szkodniki owadzie—szkodniki korzeni drzew i krzewów. Państwowe Wydawnictwo Rolnicze i Leśne, Warsaw 
Śliwa E (1993) Szkodniki korzeni drzew i krzewów. Oficyna Edytorska Wydawnictwo Świat, Warsaw

Storey GK, Gardner WA (1988) Movement of an aqueous spray of Beauveria bassiana into the profile of four Georgia soils. Environ Entomol 17:135-139

Strasser H, Enkerli J (2001) Biological control of Melolontha melolontha with Melocont ${ }^{\circledR}$-Pilzgerste based on Beauveria brongniartii: long term study in pastures from 1994 to 2000. In: Proceedings of $34^{\text {th }}$ annual meetings of the Society of Invertebrate Pathology, Noordwijkerhout, Netherlands, p 71

Strasser H, Schinner F (1996) Current status of Melolontha melolontha control by the fungus Beauveria brongniartii in Austria. IOBC/WPRS Bull 19:69-73

Strasser H, Forer A, Schinner F (1996) Development of media for the selective isolation and maintenance of virulence of Beauveria brongniartii. In: Jackson TA, Glare TR (eds) Proc $3^{\text {rd }}$ international workshop on microbial control of soil dwelling pests. AgResearch, Lincoln, pp 125-130

Strasser H, Vey A, Butt TM (2000) Are there any risks in using entomopathogenic fungi for pest control, with particular reference to the bioactive metabolites of Metarhizium, Tolypocladium and Beauveria species? Biocontrol Sci Technol 10:717-735

Studdert JP, Kaya HK, Duniway JM (1990) Effect of water potential, temperature, and clay coating on survival of Beauveria bassiana conidia in loam and peat soil. J Invert Pathol 55:417-427

Sukovata L, Jaworski T, Kolk A (2015) Efficacy of Brassica juncea granulated seed meal against Melolontha grubs. Ind Crops Prod 70:260-265

Švestka M (2006) Distribution of tribes of cockchafers of the genus Melolontha in forests of the Czech Republic and the dependence of their swarming on temperature. J For Sci 52:520-530

Švestka M (2010) Changes in the abundance of Melolontha hippocastani Fabr. and Melolontha melolontha (L.) (Coleoptera: Scarabeidae) in the Czech Republic in period 2003-2009. J For Sci 56:417-428

Trzebitzky C (1996) Strain selection and epizootic features in microbial control with Beauveria brongniartii (Sacc.) Petch. IOBC/WPRS Bull 19:54-58
Vänninen I (1996) Distribution and occurrence of four entomopathogenic fungi in Finland: effect of geographical location, habitat type and soil type. Mycol Res 100:93-101

Wagenhoff E, Blum R, Delb H (2014) Spring phenology of cockchafers, Melolontha spp. (Coleoptera: Scarabaeidae), in forests of southwestern Germany: results of a 3-year survey on adult emergence, swarming flights, and oogenesis from 2009 to 2011. J For Sci 60:154-165

Marzena Niemczyk is a research associate at the Department of Silviculture and Forest Tree Genetics at the Forest Research Institute (Poland). Her particular interest is the silviculture, ecology and the implications of biotic and abiotic factors including forest management on Melolontha spp. occurrence.

Alicja Sierpińska is a research associate at the Department of Forest Protection at the Forest Research Institute (Poland). Her research topics include biological control of forest phytophagous insects, especially with the use of entomopathogenic fungi. She has many years of experience in field efficacy tests of biological plant protection products for forestry.

Anna Tereba is a research associate at the Forests Ecology Department at the Forest Research Institute (Poland). She has significant interest in the genetic processes related to the functioning and evolution of natural populations.

Karol Sokołowski is a research associate at the Laboratory of Natural Environment Chemistry at the Forest Research Institute (Poland). His main research issues are forest pedology, phytosociology and forest typology. Other scientific interests include, soil chemistry, carbon circulation in forest ecosystems and protection of habitats, particularly soils.

Pawel Przybylski is a research associate at the Department of Silviculture and Forest Tree Genetics at the Forest Research Institute (Poland). His scientific interests focus on using molecular genetics in ecological research and for forest tree breeding. 